\section{A More Perfect Torah: At the Intersection of Philology and Hermeneutics in Deuteronomy and the Temple Scroll, by Bernard M. Levin- son}

Critical Studies in the Hebrew Bible I | Winona Lake: Eisenbrauns, 2013 |xx + I42 pages | ISBN: 978-I-575506-259-4 (softback) $\$ 24.95$

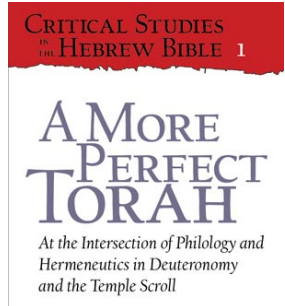

BERNARD M. LeVINSON

A More Perfect Torah contains two short yet richly rewarding studies which seek to combine what are frequently considered separate disciplinary pursuits within biblical studies, skilfully demonstrating the benefits of a broader and more integrative approach to the field. The first study consists of a lightly reworked version of Bernard M. Levinson and Molly M. Zahn's "Revelation Regained: The Hermeneutics of כי כם in the Temple Scroll," Dead Sea Discoveries 9 (2002): 295-346. It offers a compelling solution to the Temple Scroll's seemingly inconsistent replacements of כי כם where had occurred in a protasis within the Temple Scroll's pentateuchal source. More generally, the study convincingly demonstrates the importance of paying attention not only to philology and historical linguistics but also to the hermeneutical strategies of the Temple Scroll and other Rewritten Scriptures. In the second, previously unpublished, study, Levinson provides a forceful case for viewing Deut 23:23 as an interpolation into the law of vows in Deut 23:22-24. He does so by integrating traditional redaction-critical methods for detecting textual disunity with an analysis of the text's reception history. The two studies are supported by word studies contained in three appendices. An Afterword provides a short review of studies published since 2002 on the topic of the relationship between the Temple Scroll and its pentateuchal precursors, before engaging in an extended criticism of Simone Paganini's Habilitation thesis, "Nicht darfst du zu diesen Wörten etwas hinzufügen": Die Rezeption des Deuteronomiums in der Tempelrolle-Sprache, Autoren und Hermeneutik (Wiesbaden: Harrasowitz, 2009).

A More Perfect Torah is the inaugural volume in Eisenbrauns' Critical Studies in the Hebrew Bible series, which, according to the publishers' website, seeks to provide concise and succinct works on the Hebrew Bible at an affordable price while maintaining "academic rigor" and demonstrating "meticulous scholarship." It certainly delivers on those fronts, making stim- 
ulating contributions to-in particular-scholarship on the Temple Scroll and Deuteronomy, Rewritten Scripture, philology, historical linguistics, the composition history of the Pentateuch, and reception history, while also highlighting the cross-fertilisation able to be achieved between these disciplinary approaches and concerns.

In the first study, Levinson and Zahn note that the replacement of (with (אם) occurs almost only in the Temple Scroll (also once in 4QI 58 frgs IO-I 2) and only "when כunctions as a conditional to mark the protasis of a casuistic law" (6). The puzzle, then, is how to account for the Temple Scroll's anomalous renditions. To solve the puzzle, Levinson and Zahn go beyond strictly philological and historical-linguistic studies of כי and consider the hermeneutical techniques which the author of the Temple Scroll utilized when employing his biblical source texts. In particular, Levinson and Zahn note the author's tendency to harmonize contradictory laws, to bring together "thematically related laws," and to present the text as the unmediated first-person voice of God, all for the ultimate aim of presenting "a more perfect Torah-one more worthy of God" (I 4-1 5). A further inference is that the author would have had two distinct rationales for substituting with אם. The first rationale was his "desire for redactional smoothing," that is, his desire to eliminate any inconsistency in the use of כם מם resulting from differences between his pentateuchal sources (19). The second rationale was his desire for greater systematization of the laws and resulted in his "hierarchical ordering of conditionals" (22). In rewriting the pentateuchal laws, the author of the Temple Scroll consistently marked a main law by conditional and its subconditions by אם. Levinson and Zahn argue that the first rationale prompted six out of the ten replacements of wa wa wa the Temple Scroll and that the second rationale prompted the remaining four. The study thereby shows that the rewriting of Scripture in the Temple Scroll goes beyond the revision of law or the changing of Mosaic to divine voicing, extending even to such minor details as language and syntax.

Levinson and Zahn draw the broader inference that these conclusions "complicate the relationship between 'Scripture' and 'Rewritten Scripture"' (xi). They summarise that "in his re-redaction, re-systematization, and expansion of pentateuchal law, the redactor of the Temple Scroll continued the kind of editorial work that first gave rise to the Covenant Code, the legal corpus of Deuteronomy, and the Holiness Code" and which are manifest also in the Pentateuch redaction (4I). Yet as Levinson and Zahn also observe, the author of the Temple Scroll had certain goals which were distinct from 
those of the Pentateuch redactor. "The redactor of the Pentateuch sought to preserve differences" between his sources, whereas the author of the Temple Scroll sought "to lessen the redundancies and contradictions that resulted from the conservative editing of the Pentateuch" (4I).

Whereas the first study combines philological analysis with a consideration of ancient hermeneutics, the second study combines redaction criticism with an analysis of reception history. Levinson first notes the traditional redaction-critical grounds for treating the casuistic statement found in Deut 23:23 (וכי תחדל לנדר לא יהיה בך חטא ("But if you refrain from vowing, it will not count against you as a sin") as an interpolation into the law of vows in Deut $23: 22,24$. The disunity is indicated internally by the resulting unique and awkward presence of two consecutive casuistic כי clauses (Deut 23:2223) and the resulting non sequitur of the admonition in Deut 23:24, which would otherwise follow on seamlessly from the main law requiring the fulfillment of vows to Yahweh in Deut 23:22 (32, 47-48, 65-74).

The disunity is indicated externally by comparison with the law of vows in Num 30. Levinson follows Baruch Levine and Reinhard Achenbach in dating Num 30 later than Deut 23:22, 24, probably to the fourth century BCE The dating is based on such factors as a general tendency towards a diminished role for women in respect of vows, Num 30's employment of fourthcentury Aramaic legal terminology (esp. אשר: "binding agreement"), Num 30 's novel pairing of written documents with the predominantly oral vow, and the expansive nature of Num 30 vis-à-vis Deut 23:22-24. By comparing Deut 23:22-24 with Num 30, Levinson uncovers that, on the one hand, Num 30:3 contains verbatim sections of Deut 23:22, 24 and, on the other hand, Num 30:3 complete omits Deut 23:23. Given the unlikelihood of omitting the very part of the Deuteronomic law of vows which concerns refraining from vows (in the context of Num 30 's invention of the right of men to annul women's vows), Levinson judiciously concludes that it is "at least ... a possibility that Deut 23:23 was not known to the author of Numbers 30 " (77-78). The conclusion is convincing and, if anything, need not have been stated so cautiously. Furthermore, the evidence suggests a terminus a quo for the interpolation of approximately $350 \mathrm{BCE}$, which is the date for the composition of Num 30 (not " 45 O BCE," which appears to be a typo on page 78).

What makes the second study especially innovative is Levinson's use of the reception history of Deut 23:23 to adduce further evidence for interpolation. In addition to his analysis of Num 30, Levinson analyses the problems 
which Deut 23:23 has caused for modern translators, such as the NJPS translation, which inverts the protasis and apodosis in Deut 23:23 and translates the term וכי as "whereas ... if," a meaning "unattested in the legal corpus of Deuteronomy" (49). Levinson then reviews ancient interpretations and translations which rearrange the verse's order or syntax so as to reduce the dissonance in Deut 23:22-24. His argument is that the reception history of the verse implies that the interpreters or translators "recognized the textual disorder in Deuteronomy's law of vows and sought to correct it" (6o, in respect of Qoh 5:3-4). Levinson examines the Temple Scroll, the Septuagint, Qoh 5:3-4, and the opposing views of R. Meir and R. Judah in Sipre Deuteronomy. The analysis of the text's reception history thus provides strong corroboration of the redaction-critical means for detecting an interpolation in Deut 23:23. As Levinson concludes, "the history of interpretation offers a window into the composition history of Deuteronomy's law of vows" (79).

An interesting issue, which the second study does not directly address, is how we can discern whether the troubled reception of Deut 23:22-24 is primarily a result of inherent difficulties within the biblical text or of the changing ideologies of interpreters (including the evidently increased opposition to vow-making). While I am persuaded by Levinson's overall conclusion, it would nonetheless have been valuable to have had some discussion of this methodological issue. Indeed, the matter has been widely discussed in reception-oriented studies. The decision to privilege either the text's Wirkung or its Rezeption was a central point of contention, for example, in the famous debate between Wolfgang Iser and Stanley Fish in the early I980s.

The two studies in A More Perfect Torah demonstrate that historical critics must at least consider Rewritten Scripture and reception history as avenues of historical-critical inquiry. Moreover, the studies show that the evidence of Rewritten Scripture or reception history will, in certain cases, be determinative or strongly corroborative of historical-critical conclusions. The studies in this volume thus not only issue a challenge to the boundaries between disciplinary specializations within biblical studies, but significantly problematize any distinction between Scripture and Rewritten Scripture or between Bible and reception.

Deane Galbraith University of Otago 